\title{
Corrosion Behavior of Rebars Embedded in Alkali- Activated and Conventional Reactive Powder Concretes
}

\author{
Hüseyin YİĞİTER ${ }^{1}$ \\ Ahsanollah BEGLARIGALE ${ }^{2}$ \\ Serdar AYDIN ${ }^{3}$ \\ Bülent BARADAN ${ }^{4}$
}

\begin{abstract}
The present study investigated the corrosion behavior of reinforcement bars embedded in alkali-activated (ARPC) and conventional (CRPC) reactive powder concretes. Corrosion progress in $3.5 \% \mathrm{NaCl}$ solution, water and air environments were monitored up to 365 days. The physical and mechanical characteristics, such as water absorption, rapid chloride ion permeability, compressive and flexural strength, and corrosion characteristics, such as half cell potential and corrosion current intensity results were compared for ARPC and CRPC matrices. Even for the same mechanical performance, alkali-activated mortars were found to have a high permeable structure and an early depassivation of the rebars occurred. In the propagation stage of chloride induced corrosion, almost 13 times higher corrosion current intensity values were measured as well as earlier deterioration and cracking was observed for ARPC compared to CRPC.
\end{abstract}

Keywords: Reactive powder concrete, alkali-activated slag, steel rebar, chloride-induced corrosion.

\section{INTRODUCTION}

Reactive powder concrete (RPC) shows great potential for use in special applications such as nuclear structures, impact-resistant structures, skyscrapers, corrosion-resistant structures

\footnotetext{
Note:

- This paper has been received on November 2, 2018 and accepted for publication by the Editorial Board on July 17, 2019.

- Discussions on this paper will be accepted by January 31, 2021.

- https://dx.doi.org/10.18400/tekderg.478154

1 Dokuz Eylül University, Department of Civil Engineering, Izmir, Turkey - huseyin.yigiter@deu.edu.tr https://orcid.org/0000-0001-7414-8620

2 Istanbul Okan University Department of Civil Engineering, İstanbul, Turkey - ahsan.beglari@okan.edu.tr ahsan.beglari@gmail.com - https://orcid.org/0000-0002-4842-4289

3 Dokuz Eylül University, Department of Civil Engineering, Izmir, Turkey - serdar.aydin@deu.edu.tr https://orcid.org/0000-0002-0830-5357

4 Dokuz Eylül University, Department of Civil Engineering, Izmir, Turkey - bulent.baradan@deu.edu.tr https://orcid.org/0000-0001-5271-1224
} 
and pre-fabricated structural elements such as bridge bearings, security vaults, waste/transportation vessels etc. RPC has very high high compressive strength (200 - 800 $\mathrm{MPa}[1])$, fracture energy and tensile strain capacity. The basic principles for developing RPC are; enhancement of homogeneity by elimination of coarse aggregate, microstructure enhancement by heat curing, steel fiber incorporation for ductility, and densification of cementitious matrix through optimization of granular mixture, and application of pressure during setting [1-4].

The deficiency of RPC is its high heat of hydration, high drying shrinkage and high price as a result of its very high Portland cement content. Recent intensive studies performed by Aydin and Baradan [2, 5-9], showed that RPC can be produced by using alkali-activated slag without any Portland cement. These studies showed that activator solution with $4 \% \mathrm{Na}_{2} \mathrm{O}$ content and $\mathrm{M}_{\mathrm{s}}=1.2$ (solution modulus, $\mathrm{Ms}=$ mass ratio $\mathrm{SiO}_{2} / \mathrm{Na}_{2} \mathrm{O}$ ) provides optimum properties in terms of compressive strength, setting times and drying shrinkage [5,6], steam curing at $100{ }^{\circ} \mathrm{C}$ present better mechanical performance compared to autoclaving [6], silica fume act as a water reducer and shrinkage reducer in alkali activated systems in contrast to Portland cement based systems [2]. For instance, at 20\% of GGBFS replacement with SF, the water/binder ratio decreased from 0.44 to 0.20 [2]. By this way and with incorporation of $1.5 \%$ steel fiber with $13 \mathrm{~mm}$ length, alkali-activated slag based reactive powder concrete (ARPC) that has compressive strength values over $200 \mathrm{MPa}$ has been produced [8]. The mechanical properties of ARPC and conventional Portland cement based reactive powder concrete (CRPC) were given in Table 1. It should be noted that both RPC mixtures have 1.5\% steel-fiber by volume. As shown in Table 1, the flexural performance and fracture energy of steam cured ARPC were better than CRPC in the same compressive strength class. Aydin and Baradan also showed [9] that the ARPC had a better high temperature resistance as well as better adherence ability to steel when compared to CRPC. ARPC did not show explosive spalling up to $800{ }^{\circ} \mathrm{C}$ while CRPC samples suffered from explosive spalling beyond $300{ }^{\circ} \mathrm{C}$ [9]. Because of its technical advantages (lower heat of hydration, higher strength, better durability etc.) and environmental benefits (lower $\mathrm{CO}_{2}$ emission, lower energy demand, and conservation of natural resources), ARPC is a very good alternative to CRPC.

Table 1 - Properties of steam cured ARPC and CRPC [8]

\begin{tabular}{lcc}
\hline Mechanical Properties & ARPC & CRPC \\
\hline Compressive strength, $\mathrm{MPa}$ & 215.9 & 214.6 \\
Splitting tensile strength, $\mathrm{MPa}$ & 19.5 & 19.2 \\
Modulus of elasticity, GPa & 84.1 & 114.0 \\
Poisson ratio & 0.22 & 0.21 \\
Fracture energy, N/m & 16016 & 14200 \\
Flexural strength, MPa & 41.5 & 34.7 \\
\hline
\end{tabular}

On the other hand, a necessity on investigating the steel corrosion behavior embedded in alkali activated composites still exists. While some researchers concluded that alkaliactivated composites had better performance, some researchers contradict this mechanism. 
Wang, et al. [10] have stated that aluminate in the pore solution of alkali activated slag (AAS) mortar had an inhibition effect on the corrosion of steel bars after the addition of $\mathrm{NaCl}$. Silicate, another major ion in the AAS pore solution, provided a good protective effect on the steel bars in both passivation and chloride attack stages. Simulated pore solutions of AAS mortar had a greater capacity to passivate steel bars than the simulated pore solutions of Portland cement (PC) mortar and had better protective effect on steel bars from chloride ingress, especially under higher chloride concentration. Ma et al. [11] have concluded that AAS concretes had higher total chloride content at the surface than that of PC concrete. Greater ionic exchange between chloride and the hydroxyl ions and the possibly enhanced chloride binding at the surface of the AAS concretes have been identified as the possible reasons. AAS concretes were found to have lower chloride diffusivity, better pore structure, stronger interaction between hydration products and accompanying sodium, improved chloride binding. Non-steady state diffusion coefficient $\left(\mathrm{D}_{\text {nssd }}\right)$ of AAS concretes was found to be influenced by both $\mathrm{Na}_{2} \mathrm{O}$ and $\mathrm{M}_{\mathrm{s}} .6 \% \mathrm{Na}_{2} \mathrm{O}$ and $1.5 \mathrm{M}_{\mathrm{s}}$ seems optimum for reducing the rate of corrosion. Holloway and Sykes [12] have investigated the corrosion behavior of steel in alkali activated slag cement containing $\mathrm{NaCl}$ admixtures. Even the very high level of chloride admixture in alkali activated slag cement mortar, the corrosion rates of these mortars were found low. Babaee and Castel [13] showed that the low-calcium fly ash based geopolymer concrete exhibit a comparable electrochemical performance to a similar strength PC concrete during propagation phase of corrosion. Additionally, recalibration need on the some of the measurements and classification techniques for corrosion assessment, especially for the Tafel slopes, have been noted. Chaparro et al. [14] have concluded that AAS concrete presented passive corrosion behavior in the first 3 months, after which it presented decreased corrosion resistance lower than that of ordinary portland cement (OPC) concrete. Aperador et al. [15] have investigated the corrosion of steel rebars embedded in carbonated and uncarbonated alkali-activated slag and Portland cement concretes. The steel corrosion rates of AAS concretes were found to be higher than PC concretes. The highest corrosion rate was obtained with carbonated AAS concrete. Aperador et al. [15] also stated that carbonation rate was higher in AAS concrete than in the respective OPC concrete under both accelerated and laboratory environment. The high carbonation rate of AAS might be attributed to the low calcium content that leads to a low capacity to buffer the $\mathrm{pH}$ of the pore solution in AAS and also leads to rate deposits of $\mathrm{CaCO}_{3}$. Monticelli et al. [16] have characterized the corrosion behavior of reinforcing bars in alkali-activated fly ash (AAFA) mortars by corrosion potential, polarization resistance and electrochemical impedance spectroscopy measurements. AAFA mortars afforded a lower corrosion protection to the rebars and the FA mortars were found to undergo a fast carbonation so that depassivation of the rebars occurred concurrently in spite of a limited total chloride content. Higher scale porosity was found in geopolymers. After 95 days, active corrosion was started in 50\% of rebars embedded in reference mortar. On the other hand rebars in geopolymers started active corrosion after 20 days.

It seems that ARPC is a very good alternative to CRPC with its technical advantages such as mechanical strength and environmental benefits. On the other hand, the use of a newly developed material in application is significantly dependent on its durability properties, such as corrosion behavior of steel bars embedded in this mixture. Within the scope of this study, corrosion behavior of steel reinforcing bars embedded in the ARPC and CRPC matrices were investigated as well as the physical and mechanical characteristics of matrices. 


\section{EXPERIMENTAL}

\subsection{Materials}

Ground granulated blast furnace slag (GGBFS) and silica fume (SF) for ARPC, and ordinary Portland cement and SF for CRPC were used as cementitious materials. GGBFS was procured from Ereğli steel plant with the chemical composition presented in Table 2. Blaine specific surface area value of GGBFS was $410 \mathrm{~m}^{2} / \mathrm{kg}$, and $90 \%$ of particles were smaller than $45 \mu \mathrm{m}$. CEM I 42.5 type OPC with $369 \mathrm{~m}^{2} / \mathrm{kg}$ Blaine fineness, and a commercial SF with BET fineness of $23360 \mathrm{~m}^{2} / \mathrm{kg}$ have been used. The chemical compositions of PC and SF were also presented in Table 2 . A commercial quartz sand with a maximum size of $3 \mathrm{~mm}$ was used as aggregate. The particle size distribution curves of SF/GGBFS and quartz aggregate were shown in Figs. 1 and 2, respectively.

Table 2 - Chemical composition of cementitious materials

\begin{tabular}{lccccccccc}
\hline & $\mathrm{SiO}_{2}$ & $\mathrm{Fe}_{2} \mathrm{O}_{3}$ & $\mathrm{Al}_{2} \mathrm{O}_{3}$ & $\mathrm{CaO}$ & $\mathrm{MgO}$ & $\mathrm{Na}_{2} \mathrm{O}$ & $\mathrm{K}_{2} \mathrm{O}$ & $\mathrm{SO}_{3}$ & $\begin{array}{c}\text { Loss on } \\
\text { ignition }\end{array}$ \\
\hline GGBFS & 40.20 & 1.68 & 11.66 & 35.90 & 5.88 & 0.30 & 1.47 & 0.90 & 0.88 \\
$\mathrm{PC}$ & 19.10 & 3.96 & 4.40 & 61.85 & 2.05 & 0.27 & 0.70 & 3.72 & 1.82 \\
$\mathrm{SF}$ & 96.10 & - & - & - & - & - & - & - & 1.81 \\
\hline
\end{tabular}

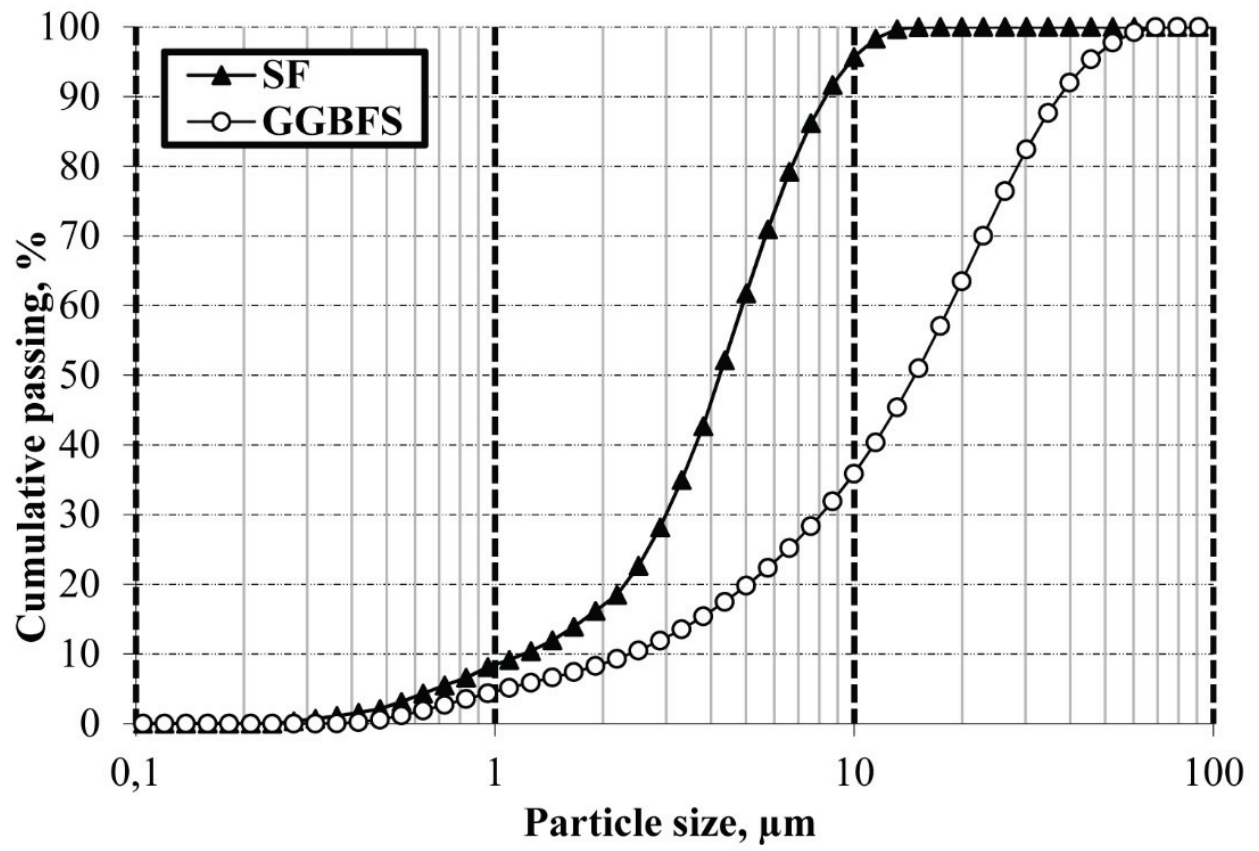

Figure 1 - Particle size distribution of SF and GGBFS 


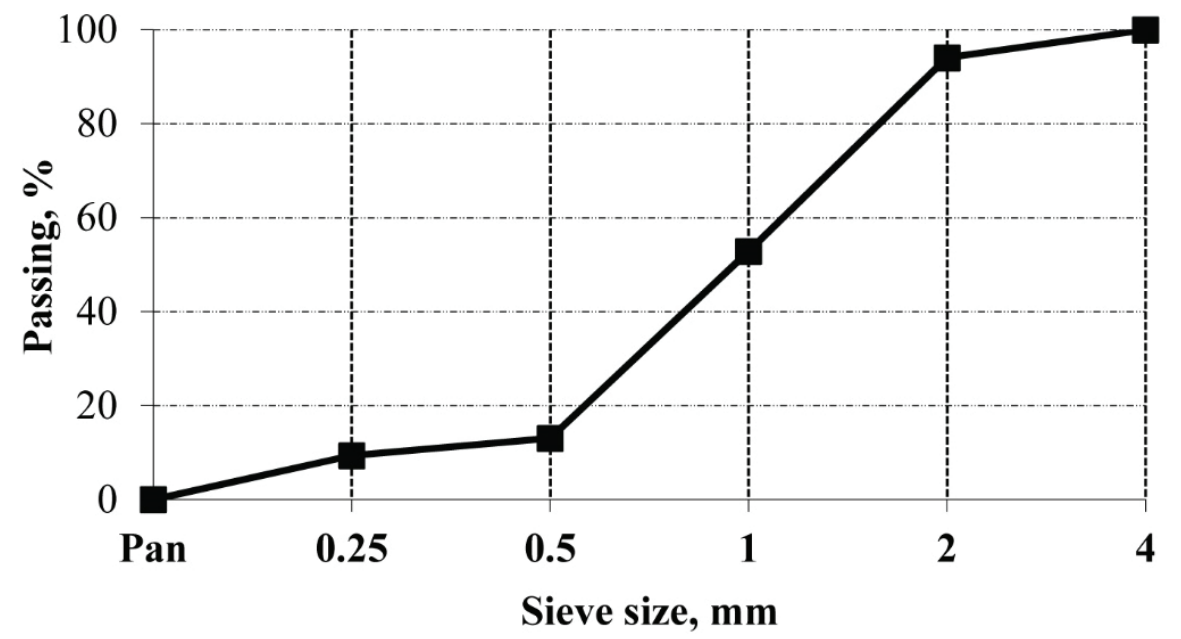

Figure 2 - Particle size distribution of quartz aggregate

ARPC has been produced by the activation of GGBFS and SF with the mixture of technical grade sodium hydroxide and sodium silicate providing silicate modulus $\left(\mathrm{M}_{\mathrm{s}}=\mathrm{SiO}_{2} / \mathrm{Na}_{2} \mathrm{O}\right)$ in the solution 1.2 and $\mathrm{Na}_{2} \mathrm{O}$ was $4 \%$ by binder weight. A polycarboxylate-based superplasticizer with a $40 \%$ solid content has been used in CRPC production.

The compositions of ARPC and CRPC based on previous studies $[8,9]$ were given in Table 3. In order to produce an ARPC with compressive strength of RPC class, the water/binder ratio of the concrete must be at about 0.20 . In conventional RPC, the water/binder ratio can be reduced to 0.20 by using high range water reducer (superplasticizers). However, in the alkali-activated binders, the superplasticizers do not show any water-reducing effect. This effect can only be achieved by silica fume replacement with slag. For conventional RPC class concrete with Portland cement binder, the high compressive strength values can be obtained thanks to silica fume's filler effect and strong pozzolanic properties. It should be noted that the previous study [7] showed that the optimum SF replacement percentage for ARPC was $20 \%$ by weight of total binder (GGBFS+SF). The lower dosages caused to inadequate setting time and workability while the higher dosages resulted in very high viscosity. Thus, silica fume contents of both RPC mixtures were selected as $20 \%$. In the preparation of ARPC, the powders were dry-mixed at low speed ( $99 \mathrm{rev} / \mathrm{min}$ ) in a pan type special designed mixer for about 1 minute. After the introduction of activator solution, materials were mixed at a low speed $(99 \mathrm{rev} / \mathrm{min}$ ) for a minute then at a high speed (440 rev/min) for about 2 minutes. Aggregates were added to pre-mixed composition and mixed at the same high speed for about 2 minutes. A similar procedure was applied for the production of CRPC samples. The mixtures were cast into molds, and compacted by hand operations and vibration. Pressure was not applied to the fresh samples. The specimens were kept in the molds for $5 \mathrm{~h}$ at room temperature of $\sim 20^{\circ} \mathrm{C}$. Then, the specimens were subjected to steam curing at $100^{\circ} \mathrm{C}$ for 12 $\mathrm{h}$ at a heating rate of $22^{\circ} \mathrm{C} / \mathrm{h}$. 
Corrosion Behavior of Rebars Embedded in Alkali-Activated and Conventional ...

Table 3 - Mixture proportions for ARPC and CRPC

\begin{tabular}{lcc}
\hline Components & ARPC & CRPC \\
\hline GGBFS, $\mathrm{kg} / \mathrm{m}^{3}$ & 720.0 & -- \\
$\mathrm{PC}, \mathrm{kg} / \mathrm{m}^{3}$ & -- & 720.0 \\
$\mathrm{SF}, \mathrm{kg} / \mathrm{m}^{3}$ & 180.0 & 180.0 \\
Quartz $(1-3 \mathrm{~mm}), \mathrm{kg} / \mathrm{m}^{3}$ & 543.2 & 575.3 \\
Quartz $(0.6-1.2 \mathrm{~mm}), \mathrm{kg} / \mathrm{m}^{3}$ & 422.5 & 447.5 \\
Quartz $(0-400 \mu \mathrm{m}), \mathrm{kg} / \mathrm{m}^{3}$ & 144.9 & 153.4 \\
Quartz $(0-75 \mu \mathrm{m}), \mathrm{kg} / \mathrm{m}^{3}$ & 96.6 & 102.3 \\
Waterglass, $\mathrm{kg} / \mathrm{m}^{3}$ & 160.0 & -- \\
NaOH, $\mathrm{kg} / \mathrm{m}^{3}$ & 30.9 & -- \\
Water, $\mathrm{kg} / \mathrm{m}^{3}$ & 49.0 & 123.0 \\
Superplasticizer, $\mathrm{kg} / \mathrm{m}^{3}$ & -- & 50.0 \\
Water/binder ratio & 0.17 & 0.17 \\
Aggregated/binder ratio & 1.34 & 1.42 \\
\hline
\end{tabular}

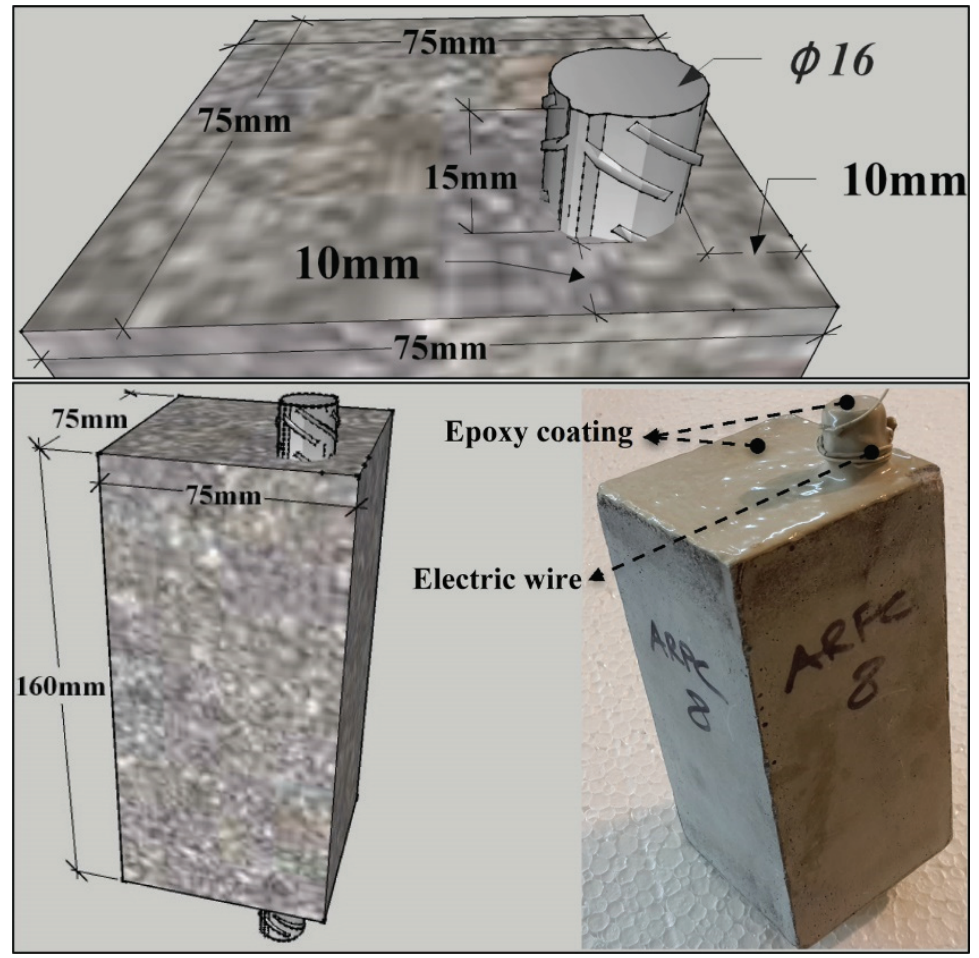

Figure 3 - Details of corrosion test specimens 
The schematic figure of corrosion test specimen and its details are presented in Fig. 3. S420 grade deformed steel rebar (yield strength of $511 \mathrm{MPa}$, tensile strength $605 \mathrm{MPa}$, strain capacity at failure $21 \%$ ) with a diameter of $16 \mathrm{~mm}$ was used. For corrosion tests, an electric wire was mounted on one of the free ends of the rebar. The upper and lower surface of the specimens and also free ends of the rebar were carefully sealed by epoxy coating. The first group of specimens was subjected to wetting-drying cycles in $3.5 \% \mathrm{NaCl}$ solution. The corrosion process of specimens was monitored after 200, 400, 1400 wetting-drying cycles. It must be mentioned that the 1400 wetting-drying cycles lasted in 360 days. The second and third groups of specimens were kept in water and in air at laboratory conditions, respectively, for 360 days.

\subsection{Measurements}

Flexural strength of the mixtures was determined on three prismatic specimens $(40 \mathrm{x} 40 \mathrm{x}$ $160 \mathrm{~mm})$. Compressive strength values were determined on broken specimen pieces $(40 \mathrm{x} 40$ $\mathrm{mm}$ ) left from flexural test.

The sorptivity values of RPC matrices were determined on three prismatic specimens ( $40 \mathrm{x}$ $40 \times 160 \mathrm{~mm}$ ) by the measurement of water absorption by capillary rise. The specimens were dried at $105 \pm 5^{\circ} \mathrm{C}$ to achieve constant weight. Side surfaces of the samples were coated to prevent absorption through side surfaces. Then the specimens were kept in a water tray with small supports and the water level was maintained in such a way that only $3 \mathrm{~mm}$ of the specimens were submerged in water. The weight measurements were recorded for $48 \mathrm{~h}$.

The volume of permeable voids and total water absorption capacity of mortar specimens were determined on the three disk specimens with a radius of $100 \mathrm{~mm}$ and $50 \mathrm{~mm}$ height according to ASTM C642 [17]. The specimens were dried at $105 \pm 5^{\circ} \mathrm{C}$ to constant weight. After cooling the specimens were weighted (A). The specimens were immersed in water for $72 \mathrm{~h}$ and weighed (B). Then the specimens were boiled in water for $5 \mathrm{~h}$, then surface moisture was removed and the saturated surface dry weight was measured (C). Finally, apparent volume of samples boiled in water was determined using Archimedes' scales (D). Total water absorption and volume of permeable voids, $\mathrm{V}_{\mathrm{pv}}$ determined by using Eq. 1 and 2, respectively.

Water absorption $(\%)=[(\mathrm{B}-\mathrm{A}) / \mathrm{A}] \times 100$

Volume of permeable voids $(\%)=[(\mathrm{C}-\mathrm{A}) /(\mathrm{C}-\mathrm{D})] \times 100$

The rapid chloride permeability (RCPT) tests were performed on cylindrical specimens with $100 \mathrm{~mm}$ diameter and $50 \mathrm{~mm}$ thickness according to the ASTM C 1202 standard [18].

The open-circuit potential ( $\left.\mathrm{E}_{\mathrm{OCP}}\right)$ and corrosion current density $\left(\mathrm{i}_{\text {corr }}\right)$ values of the specimens were obtained using a computer-controlled potentiostat, Gamry Interface1000, through a three-electrode system (Fig. 4). The working electrode was the rebar embedded in the concrete matrices. Saturated calomel electrode (SCE) and graphite were used as the reference electrode and counter electrode, respectively. The $\mathrm{E}_{\mathrm{OCP}}$ measurements were carried out for at least $60 \mathrm{~min}$ to obtain a steady state condition. Immediately after EOCP measurement the potentiodynamic polarization curves were obtained in the $\pm 150 \mathrm{mV}$ range of EOCP with scan 
rate of $0.2 \mathrm{mV} / \mathrm{s}$. The corrosion current density has been analyzed through the Tafel analysis. It must be noted that the electrolytic environment of three-electrode system was the $3.5 \%$ $\mathrm{NaCl}$ solution.

Pore-size distributions of the samples were determined by the Mercury Intrusion Porosimetry (MIP) method.

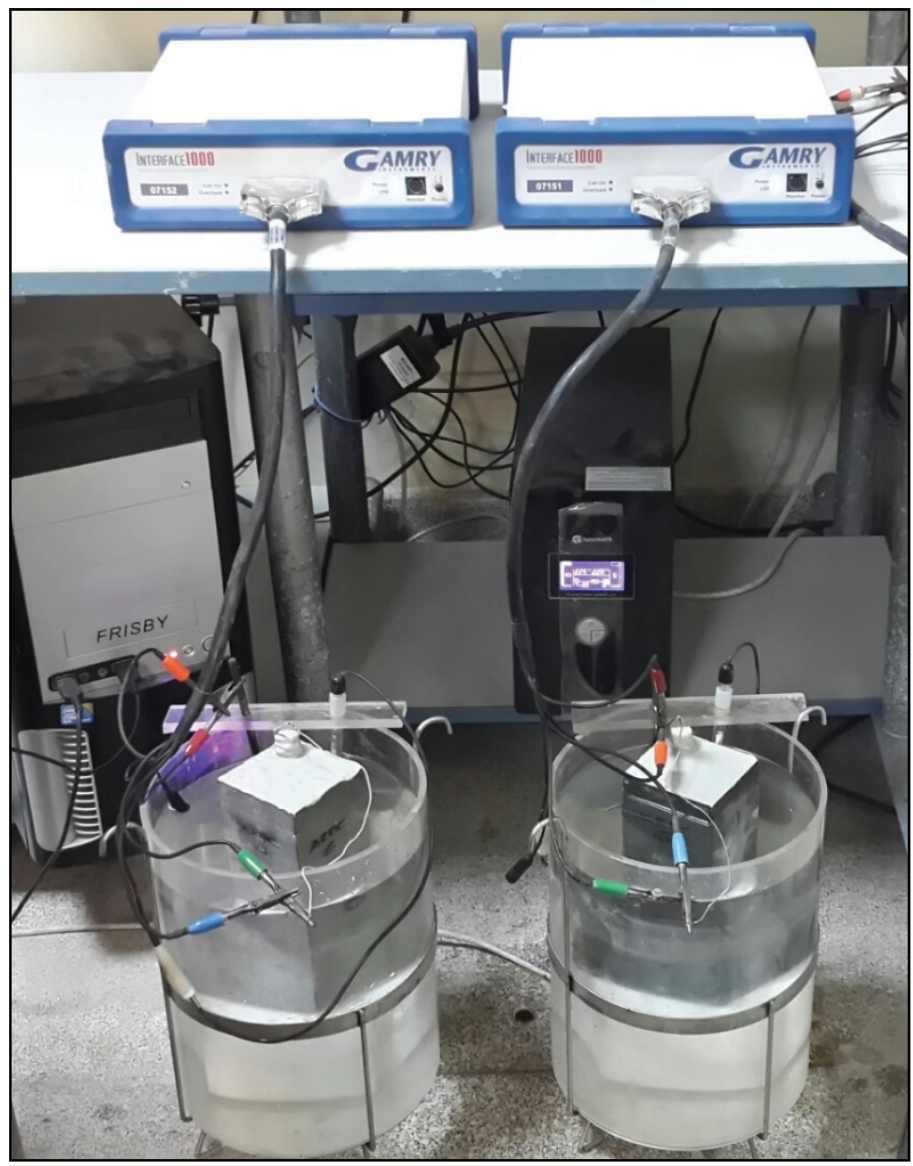

Figure 4 - Corrosion test setup.

\section{RESULTS AND DISCUSSION}

\subsection{Workability and Mechanical Properties}

Fresh state flow diameter, compressive strength and flexural strength values of ARPC and CRPC matrices without steel fiber were given in Table 4. As shown in Table 4, both RPC matrices have a quite high workability. The compressive strength values of ARPC and CRPC matrices were about $134 \mathrm{MPa}$ while the flexural strength of ARPC was about $22 \%$ higher than CRPC. 
Table 4 - Workability and mechanical properties of ARPC and CRPC matrices.

\begin{tabular}{ccc}
\hline & ARPC matrix & CRPC matrix \\
\hline Flow diameter, mm & 167 & 186 \\
Compressive strength, $\mathrm{MPa}$ & 133.3 & 135.1 \\
Flexural strength, $\mathrm{MPa}$ & 12.4 & 10.2 \\
\hline
\end{tabular}

\subsection{Physical properties}

Fig. 5 shows the capillary water absorption of RPC matrices. As shown in Fig. 5 the capillary water absorption of ARPC matrix was significantly higher than CRPC. As expected, the slope of capillary water absorption curves for both RPC matrices reduced with elapsed time. For CRPC matrix, the capillary water absorption ceased beyond 24 hours. However, matrix phase of ARPC continued to capillary water movement up to 48 hours. Capillary water suction value of CRPC matrix at 48 hours was about one-third of the ARPC's value. The volume of permeable voids and total water absorption by weight of ARPC and CRPC matrices are presented in Fig. 6. Parallel to capillary water absorption test results, the amount of permeable voids and total water absorption of ARPC matrix were about four times higher than CRPC.

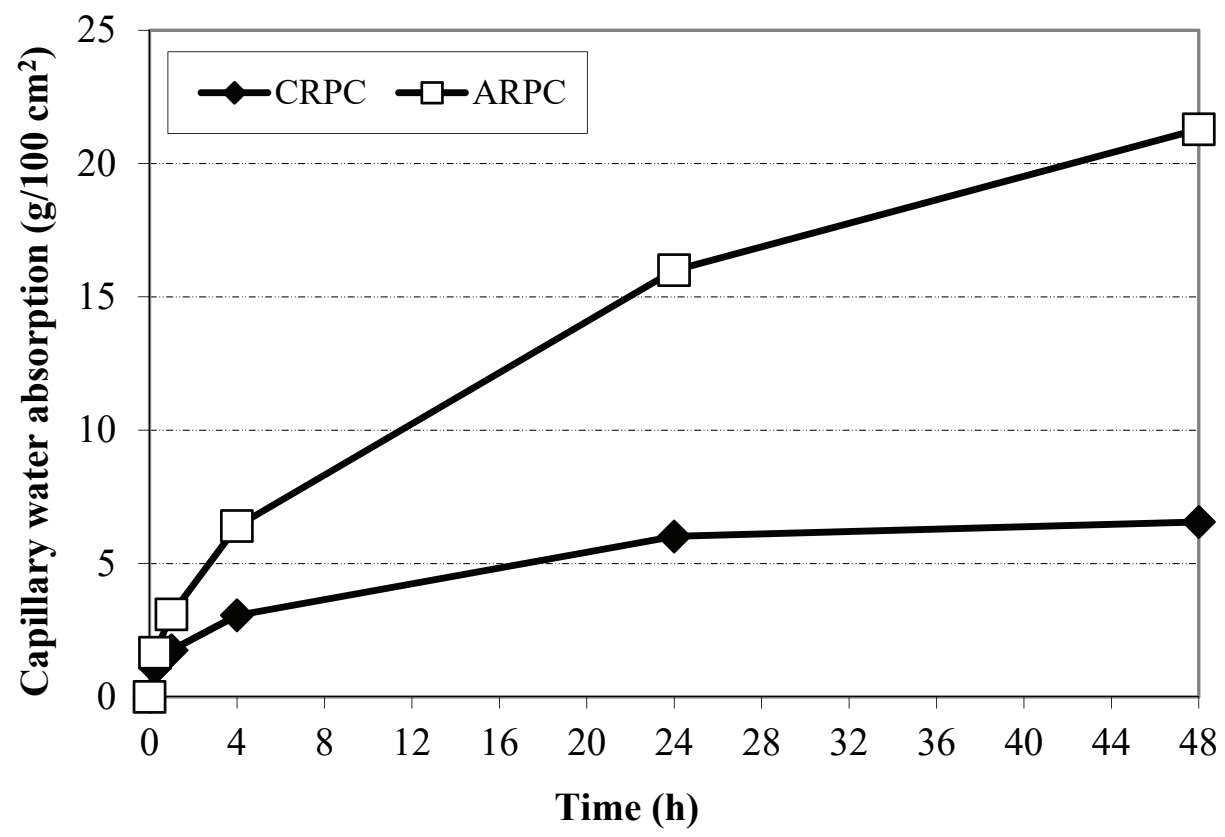

Figure 5 - Capillary water absorption of ARPC and CRPC

Pore size distribution of ARPC and CRPC matrices were presented in Fig. 7. As shown in Fig. 7, pores in cement-based materials can be categorized as gel pores, capillary pores and 
macro pores. Macro pores mainly influence the mechanical properties while the capillary pores affect the permeability and mechanical properties [19]. As shown in Fig. 7, ARPC have a coarser pore size distribution compared to CRPC. The pores in CRPC were generally lower than $0.008 \mu \mathrm{m}$ and can be classified as gel pores. The amount of gel, capillary and macro pores in ARPC was significantly higher than those of CRPC. The high amount of capillary pores in ARPC explains its higher permeability compared to CRPC.

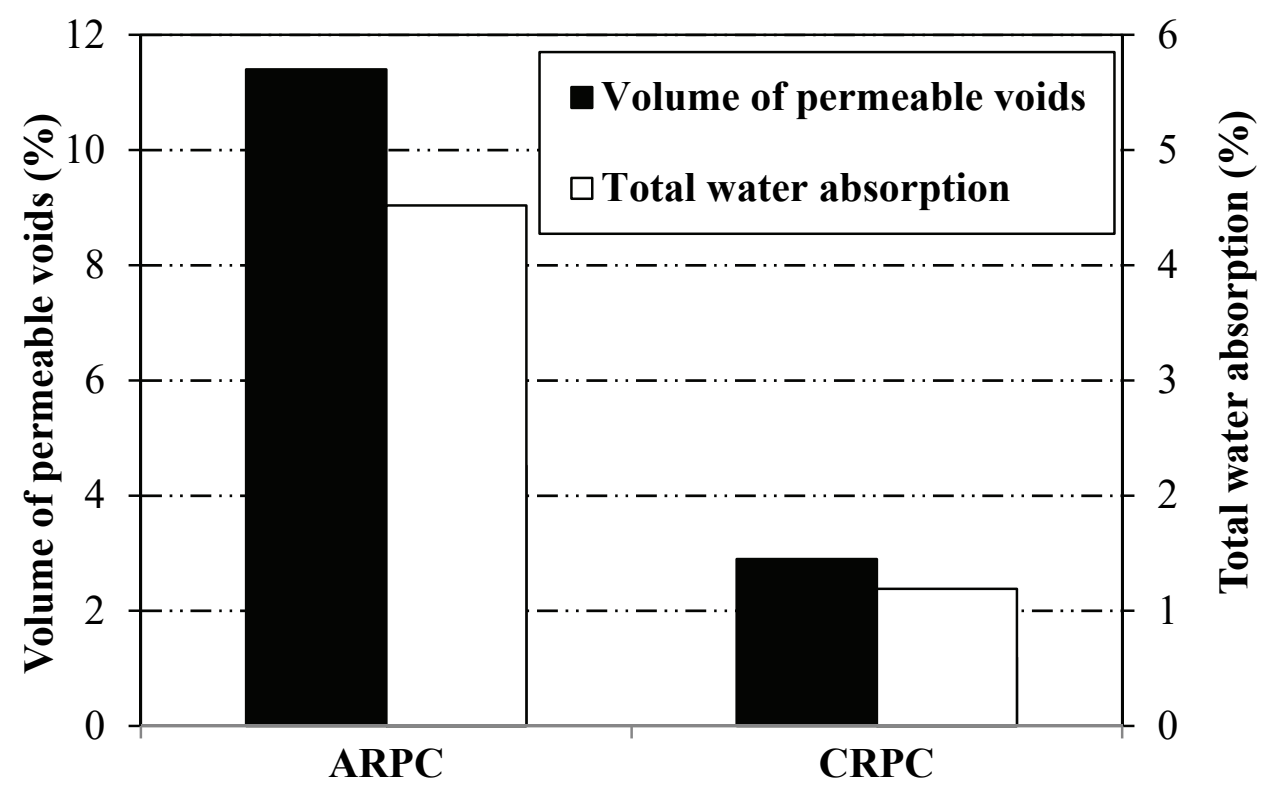

Figure 6 - Volume of permeable voids and total water absorption of mixtures.

From the stand point of electrical indication of concrete's ability to resist chloride ion penetration, there was no any charge passing in the CRPC mixture, whereas in the ARPC mixture there was 700 coulombs after 6 hours. Concretes are divided into five permeability classes according to the ASTM C1202 standard classification. According to this classification, the chloride permeability for CRPC was "negligible", while the ARPC mixture was "very low". RCPT is a measurement based on the electrical conductivity of concrete and depends on the pore structure of the concrete and also the chemistry of the pore solution. The higher amount of charge passing through the ARPC mixture as compared to the CRPC mixture can be attributed to the more porous structure of ARPC, but mainly to the change in the chemical composition of the pore solution of these concretes. Najimi and Ghafoori [20] have reported that the RCPT can give pessimist results in the case of alkali activated cement. They have stated that the high alkali ion concentrations in the pore solution of these materials increase the electrical conductivity remarkably. From the obtained data, it can be said that the electrical resistance of the ARPC mixture was lower than the CRPC mixture. However, it is thought that the experimental results do not give a good information about the chloride ion permeability for the reasons mentioned above. 


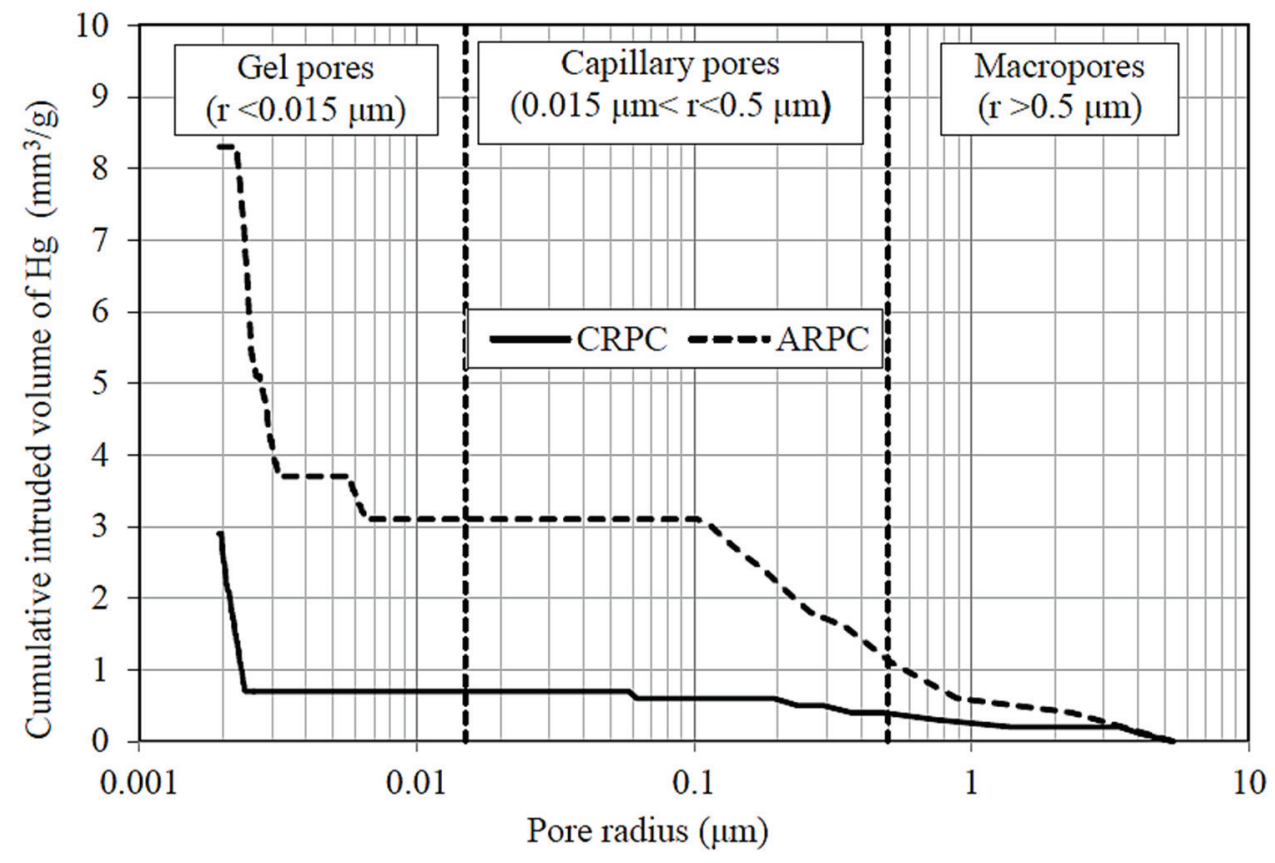

Figure 7 - Pore size distribution of ARPC and CRPC.

\subsection{Rebar Corrosion}

The $\mathrm{E}_{\mathrm{OCP}}$, which was measured relative to the $\mathrm{SCE}$ as the reference electrode, is a parameter to predict the corrosion potential of reinforcing steel in concrete (ASTMC876). ASTMC876 [21] recommends that there is a greater than $90 \%$ probability of corrosion in the case of potential less than $-270 \mathrm{mV}$. A corrosion potential more positive than $-120 \mathrm{mV}$ shows that there is a greater than $90 \%$ probability that no corrosion is occurring. Also, an $\mathrm{E}_{\mathrm{OCP}}$ value between $-120 \mathrm{mV}$ to $-270 \mathrm{mV}$ represents uncertain corrosion activity. The average $\mathrm{E}_{\mathrm{OCP}}$ values of specimens kept in water and air are presented in Fig. 8. The specimens stored in air, no matter the mixture type, were in passive state at the end of the 365 days. The lack of humidity in the pore system conserved the reinforcement against the corrosion activity. Passive position of the reinforcement was valid for the CRPC specimens kept in standard water curing. It can be explained by the impermeable pore structure of CRPC, which can keep the steel bars in passive state. On the other hand, a depassivation seemed to occur at approximately 20 days for ARPC specimens in water curing. Pore structure analysis of the specimens showed that ARPC specimens had approximately 4 times greater permeable voids than CRPC specimens. Electrochemical potential activity seemed to start even in presence of humidity by ingress of water into ARPC specimens. Although, it means that corrosion activity risk was greater than $90 \%$ probability, this corrosion activity could not detected in observational and microscopic studies. Fig. 9 shows the rebars embedded in the specimens that were kept in water for 360 days. There was no evidence of corrosion on the surface of 
rebars embedded in the CRPC and ARPC specimens. This finding was also supported by the by the microstructural analysis conducted on the matrix-rebar interface of these specimens.
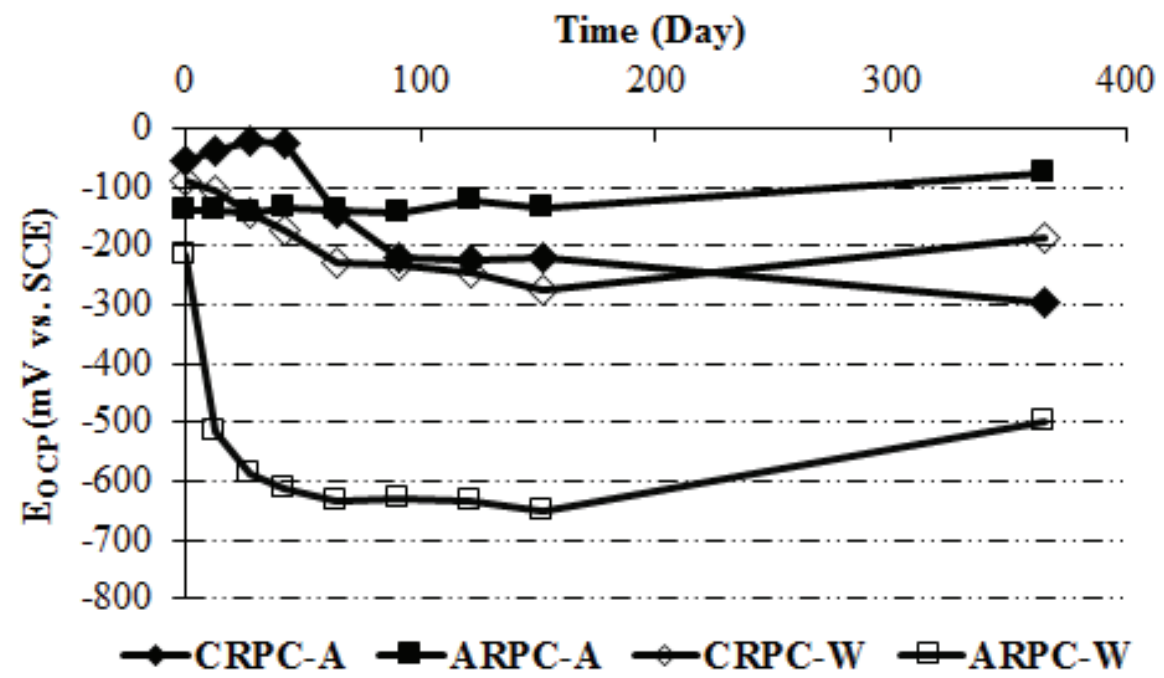

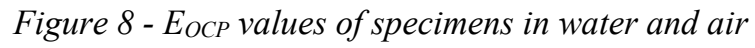
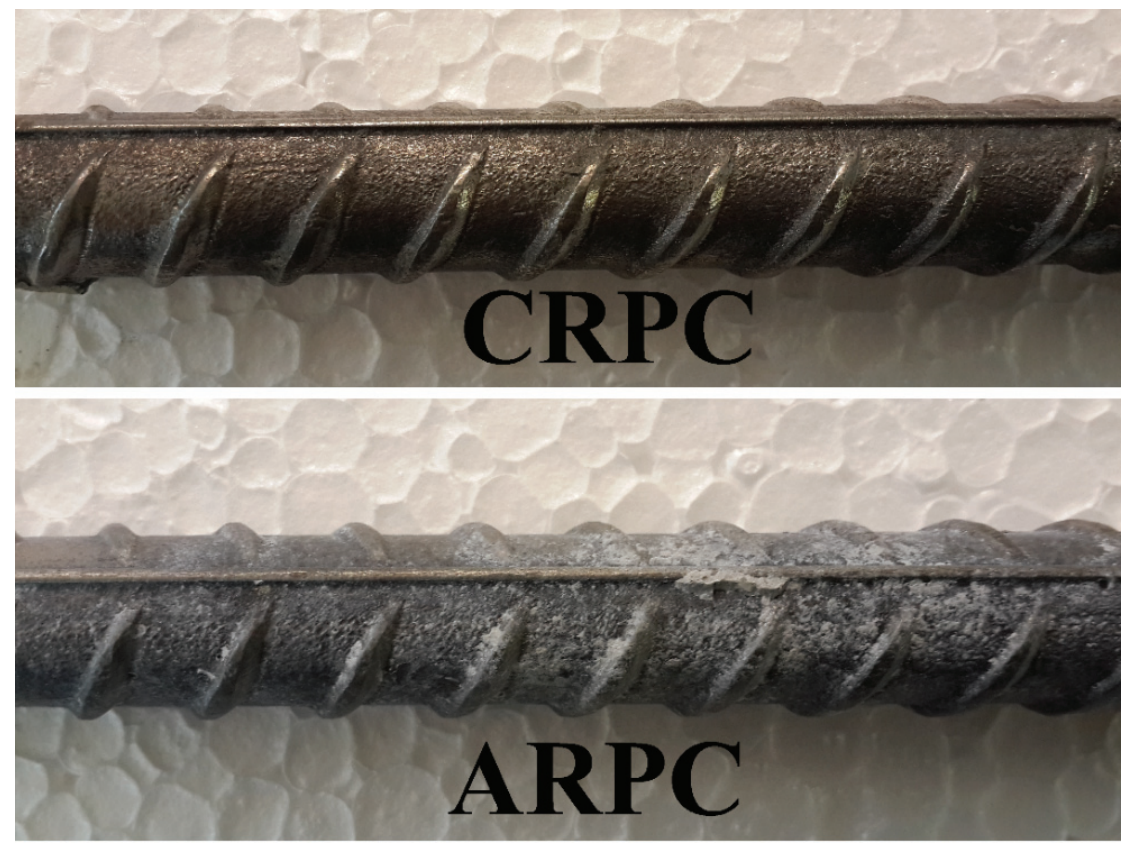

Figure 9 - The rebars embedded in the CRPC and ARPC specimens that were kept in water for 360 days. 
The average EОсP values of specimens subjected to wetting-drying cycles are presented in Fig. 10. According to the EОСP values, there was more than $90 \%$ probability that the steel rebars embedded in the CRPC mixture were not corroded up to 400 wetting-drying cycles. However, the average $E_{O C P}$ values of rebars embedded in the ARPC exceeded the $-270 \mathrm{mV}$ value and depassivation occurred even at the 50 wetting-drying cycles. The EOCP values of rebars in both of the mixtures were higher than $-600 \mathrm{mV}$ after 1400 wetting-drying cycles that showed a high potential risk of corrosion.

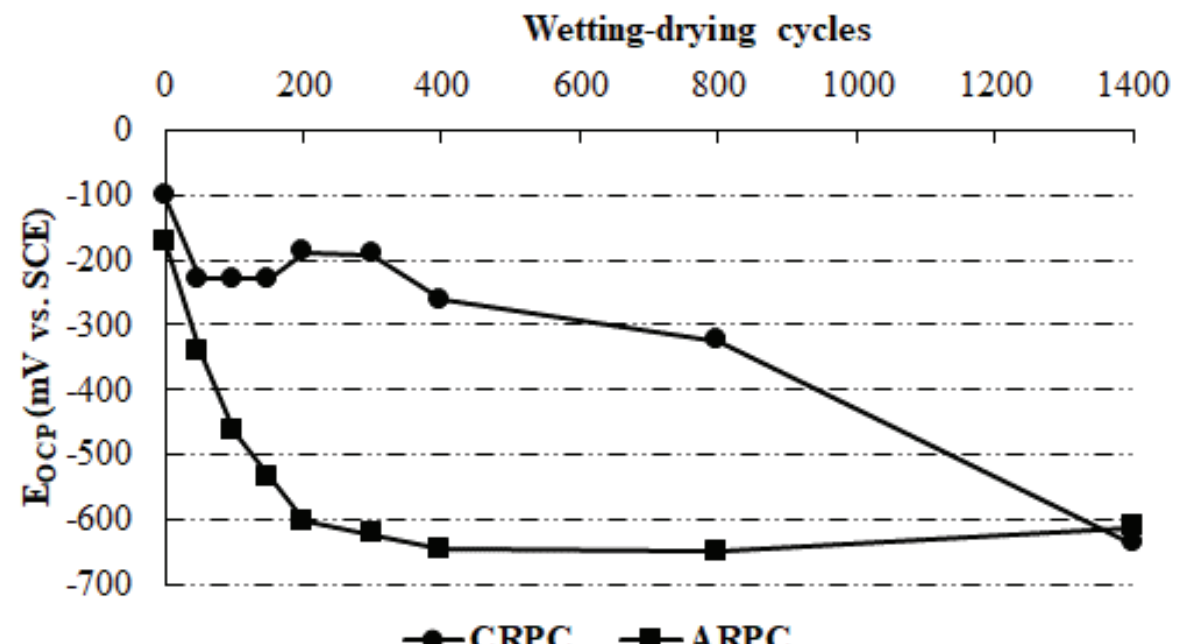

Figure 10 - EOCP values of specimens subjected to wetting-drying cycles in $\mathrm{NaCl}$ solution.

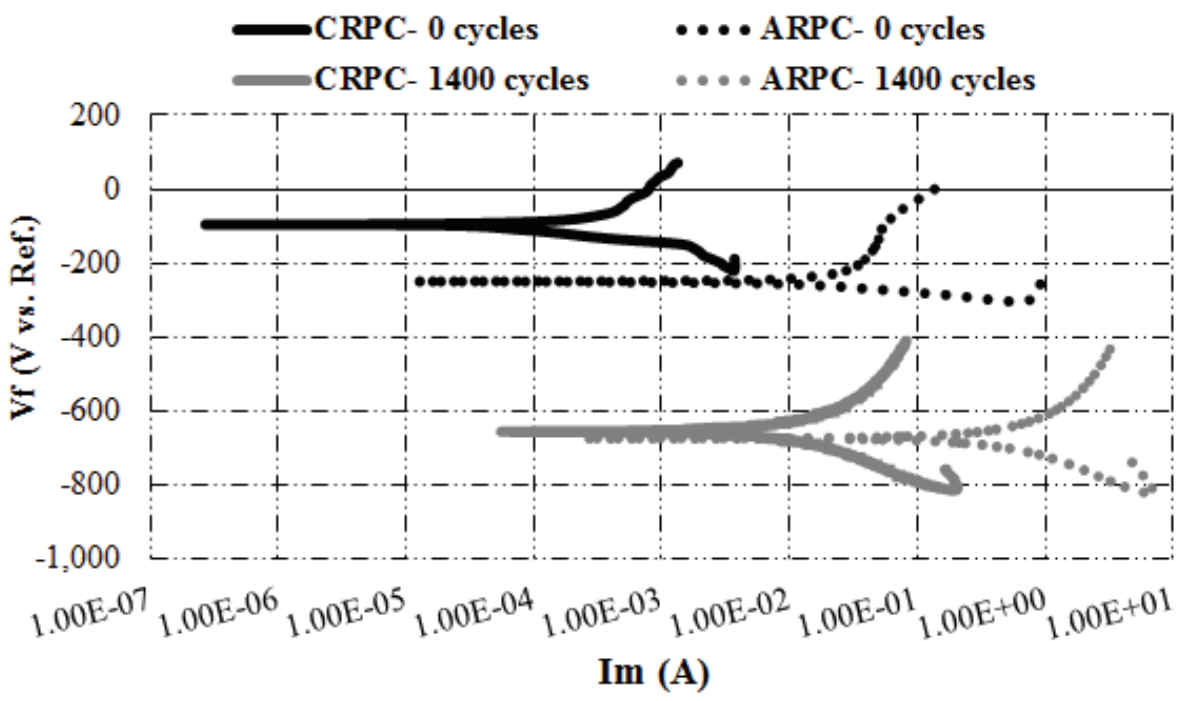

Figure 11 - Polarization curves. 


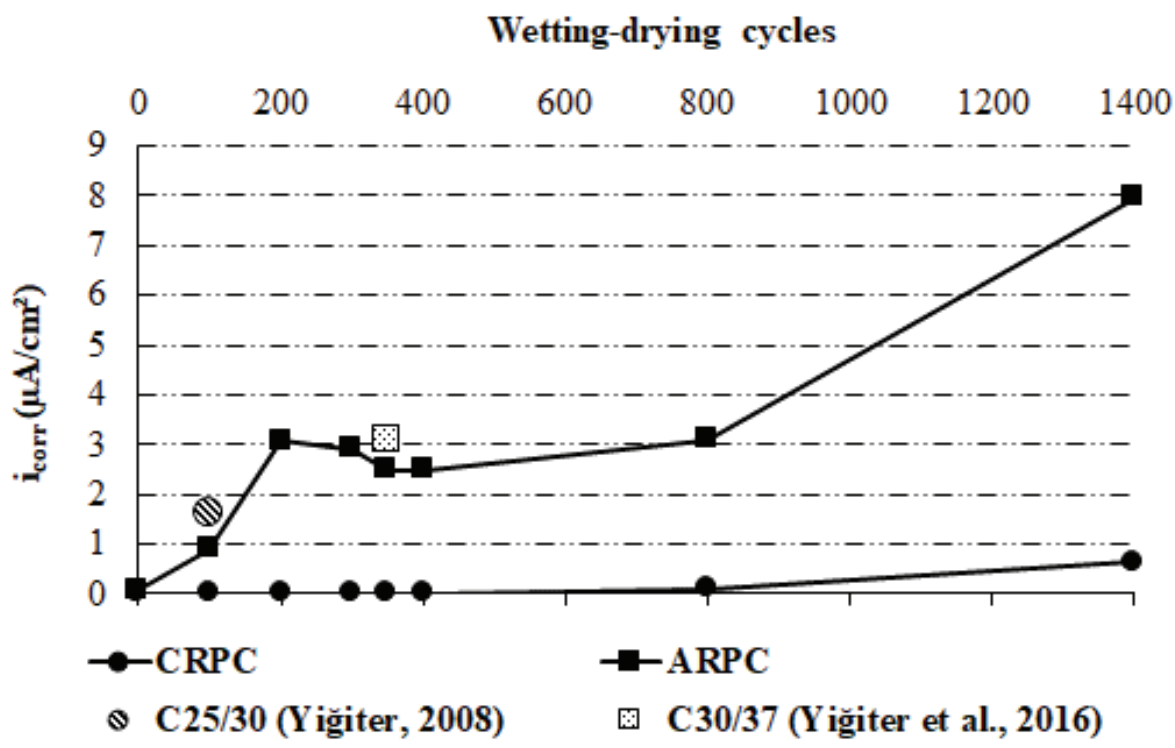

Figure 12 - $i_{\text {corr }}$ values during wetting-drying cycles

Fig. 11 shows the polarization curves of the specimens. As expected, an increase in corrosion activity shifted the intersection of Tafel slopes to greater current and lower potential values. $\mathrm{I}_{\text {corr }}$ values were calculated from Tafel analysis. It can be seen from Fig. 12 that the $\mathrm{i}_{\text {corr }}$ values were accordance with the $\mathrm{E}_{\mathrm{OCP}}$ values. After 100 wetting-drying cycles, the average $\mathrm{i}_{\text {corr }}$ values of the steel rebars embedded in the CRPC was lower than the $0.1 \mu \mathrm{A} / \mathrm{cm}^{2}$ that indicates a negligible corrosion level. However, the average $i_{\text {corr }}$ values measured in ARPC specimens was in the range of 0.5 to $1 \mu \mathrm{A} / \mathrm{cm}^{2}\left(0.9 \mu \mathrm{A} / \mathrm{cm}^{2}\right)$ that indicates a moderate corrosion level. However, the average $i_{\text {corr }}$ value of steel embedded in the CRPC can be categorized in moderate corrosion level $\left(0.64 \mu \mathrm{A} / \mathrm{cm}^{2}\right)$ after 1400 cycles. It is obvious that corrosion rate of steel rebars embedded in the ARPC increased rapidly even at a low wetting-drying cycles. The average $\mathrm{i}_{\text {corr }}$ value of steel rebar embedded in the ARPC was in the range of 2.48 to 3 $\mu \mathrm{A} / \mathrm{cm}^{2}$ (high corrosion activity) at 200, 300, 400 wetting-drying cycles.

Yiğiter [22] reported $1.6 \mu \mathrm{A} / \mathrm{cm}^{2}$ corrosion current density value at 100 wetting-drying cycles in $3.5 \%$ chloride solution (Fig. 12). In that study, $10 \mathrm{~mm}$ concrete cover and C25/30 concrete class were tested. In another study, $3.1 \mu \mathrm{A} / \mathrm{cm}^{2}$ corrosion current density value was measured from a steel reinforcement embedded with $10 \mathrm{~mm}$ cover thickness in a C30/37 grade OPC concrete subjected 350 wetting-drying cycles in real sea environment [23]. From the viewpoint of corrosion activity it can be said that, ARPC reflected a similar performance to conventional OPC mixtures.

Corrosion current density higher than $1 \mu \mathrm{A} / \mathrm{cm}^{2}$ indicates high corrosion level [24]. The average $i_{\text {corr }}$ value of steel rebars embedded in the ARPC $\left(7.96 \mu \mathrm{A} / \mathrm{cm}^{2}\right)$ was almost 13 times higher than the CRPC after 1400 wetting-drying cycles. These findings were in accordance with mass losses in the embedded rebars given in Fig. 13. 
Hüseyin YİĞITER, Ahsanollah BEGLARIGALE, Serdar AYDIN, Bülent BARADAN

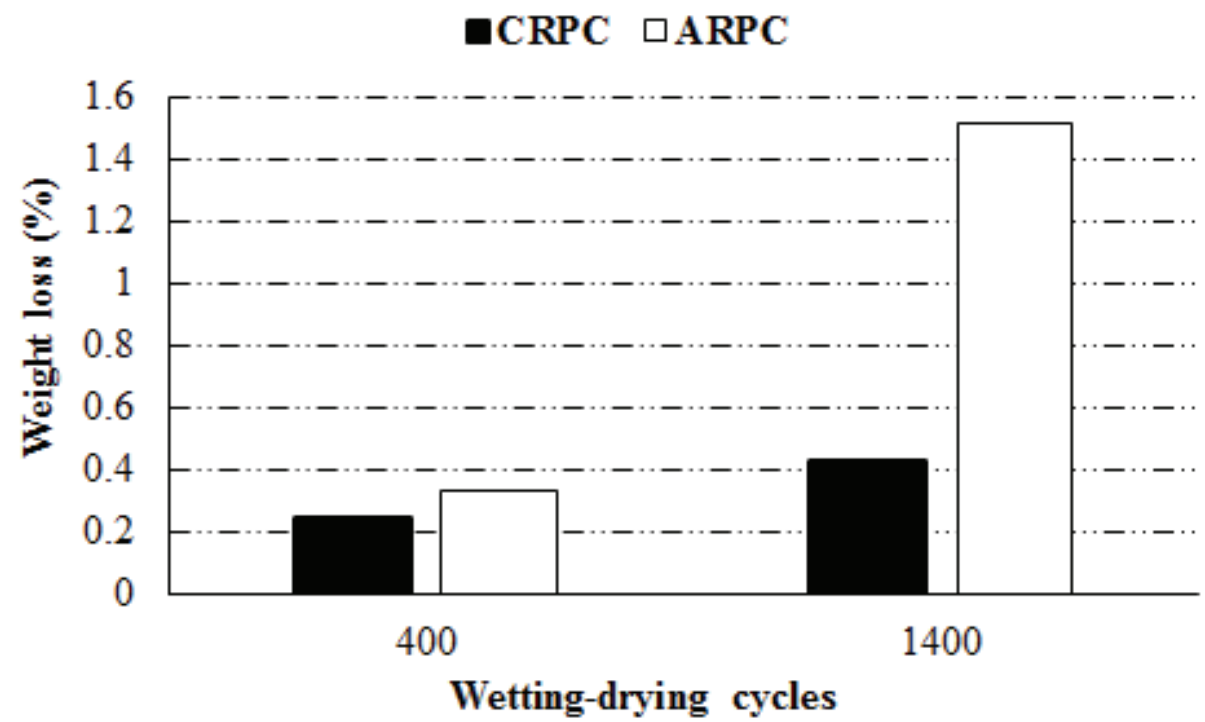

Figure 13 - Mass loss obtained from steel reinforcement

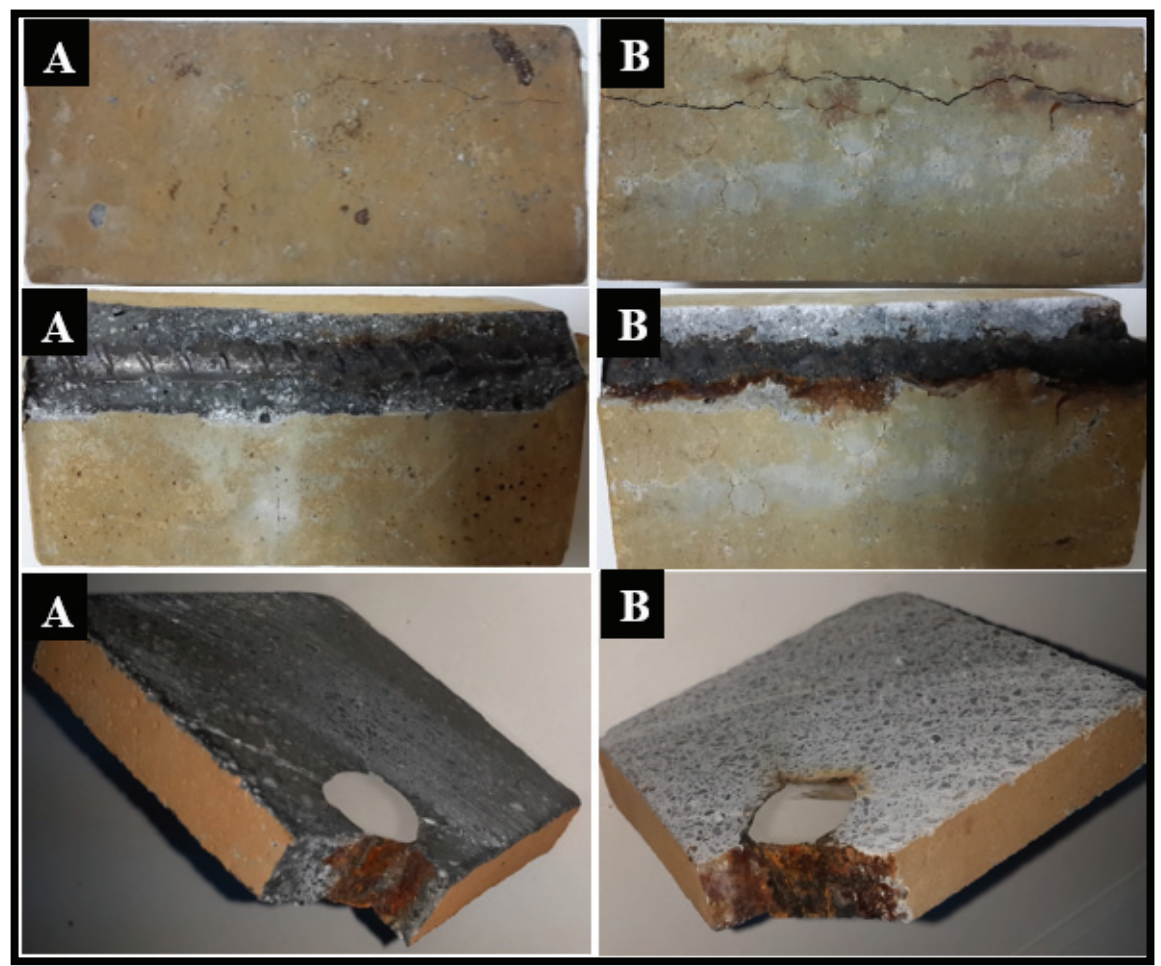

Figure 14 - A) CRPC and B) ARPC specimens after 1400 wetting-drying cycles 

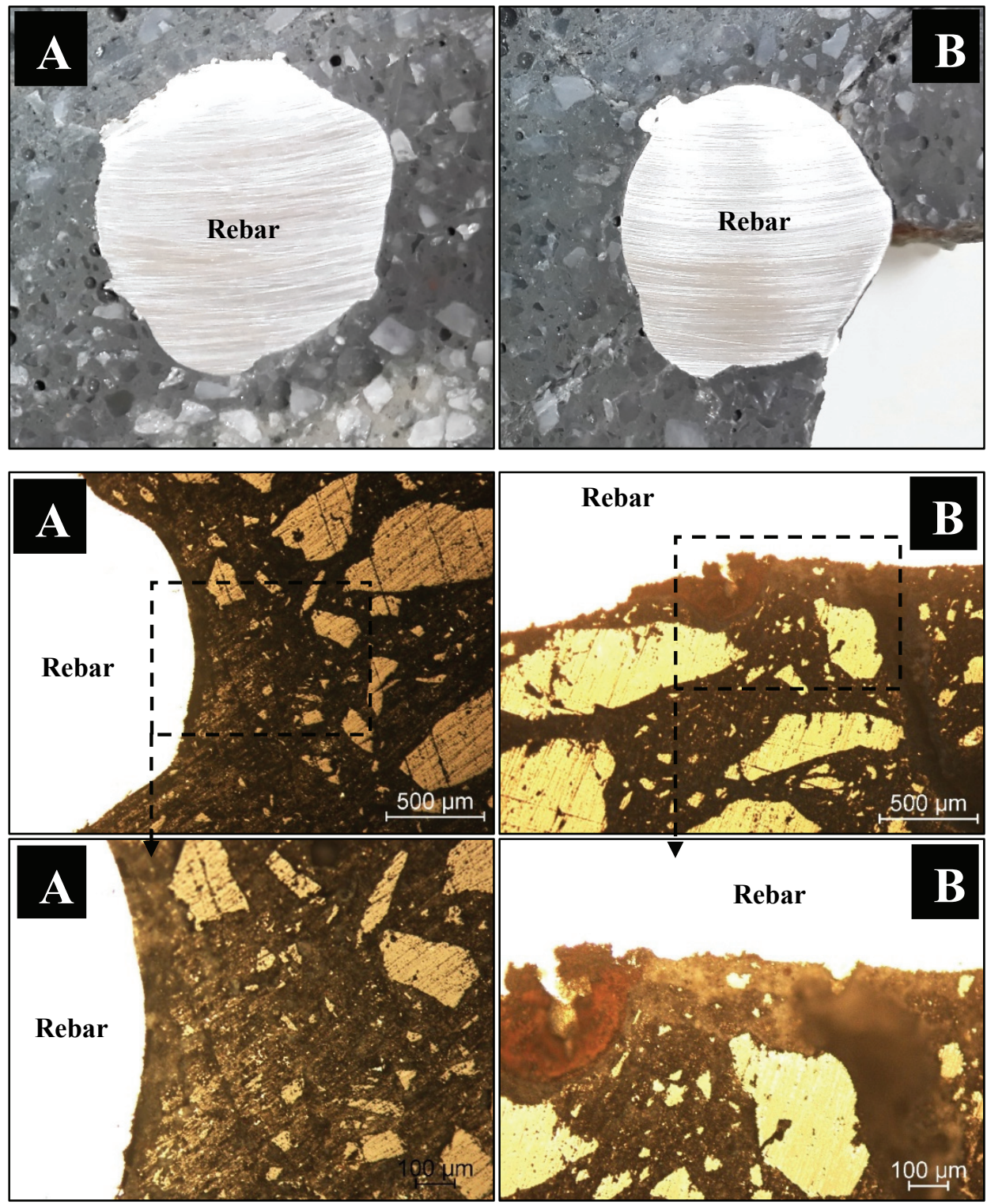

Figure 15 - A) CRPC specimen kept in water. B) CRPC specimen subjected to 1400 wetting-drying cycles.

The digital camera (DC) and optical microscope (OM) images presented in Figs. 14, 15 and 16 showed the higher corrosion-induced deterioration (after 1400 cycles) in the ARPC specimens compared in the CRPC ones. As can be seen from Fig. 14 the deterioration in concrete cover of ARPC mixture was much more obvious when compared in CRPC. Figs 15 and 16 shows the polished cross section of CRPC and ARPC specimens, respectively. It can 
be seen from the DC images the inner side of rebar embedded in ARPC was also corroded, but obviously not as much as the outer side of the rebar. This corrosion led to formation of macro cracks in the ARPC matrix. In addition, OM images revealed the existence of many micro cracks in the rebar-matrix interface of ARPC mixture (Fig. 16). SEM analysis conducted on the matrix-rebar interfaces revealed the existence of higher amount of corrosion products in ARPC as compared to CRPC. Fig. 17 shows the characteristic corrosion products with different morphology in the matrix-rebar interfaces of CRPC and ARPC.

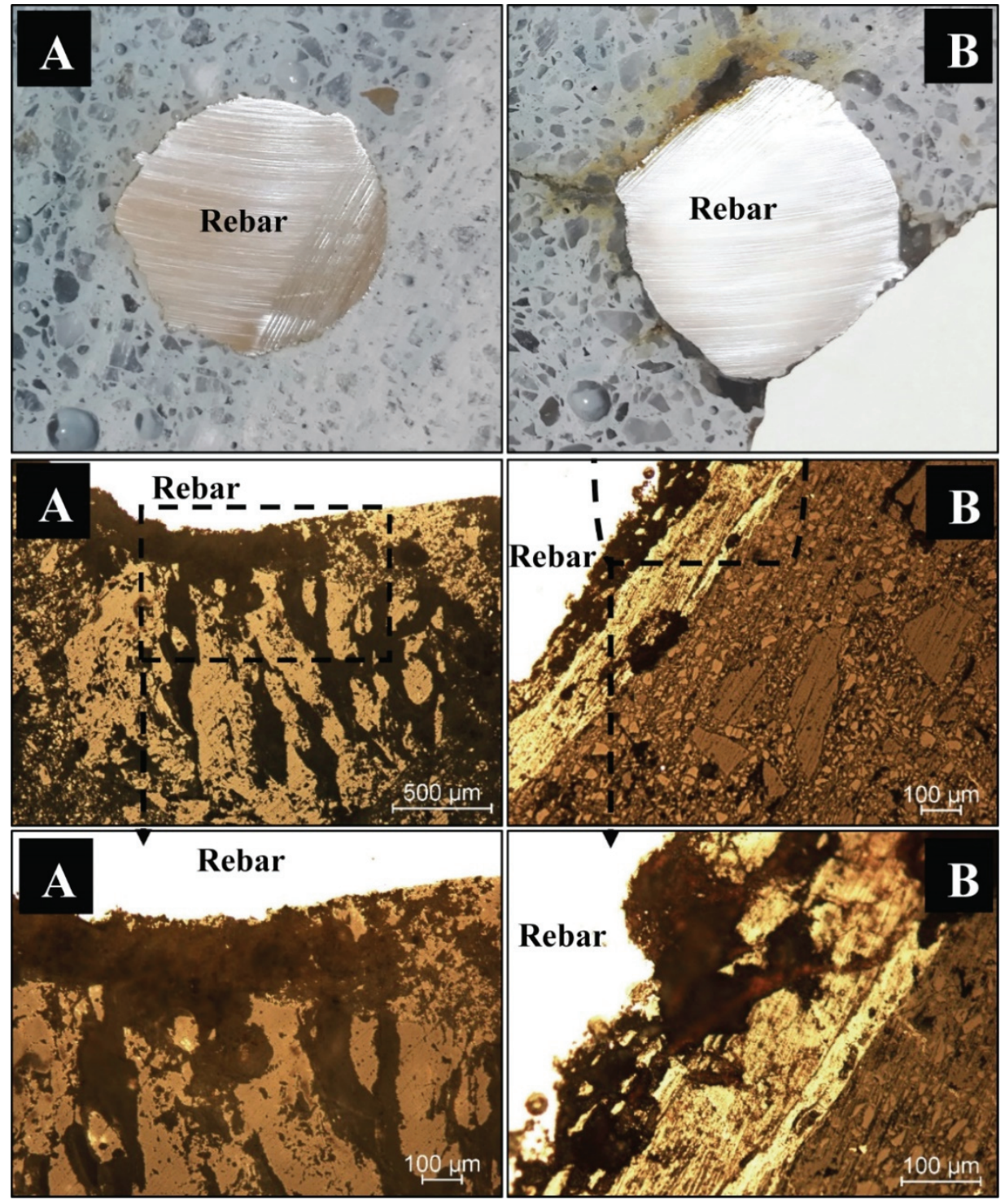

Figure 16 - A) ARPC specimen kept in water. B) ARPC specimen subjected to 1400 wetting-drying cycles. 


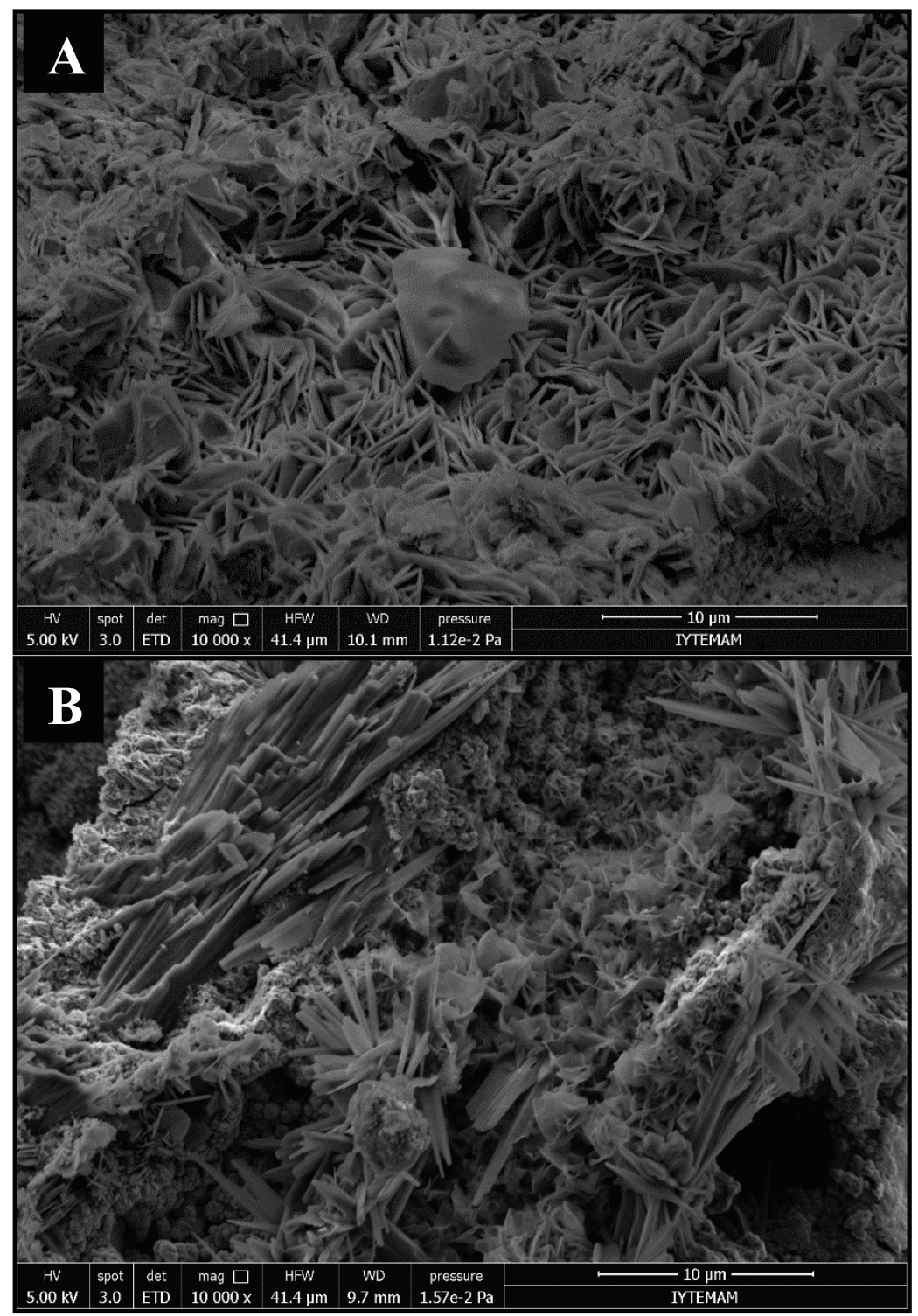

Figure 17 - SEM images of the matrix-rebar interfaces of A) CRPC and B) ARPC after 1400 wetting-drying cycles

\section{CONCLUSION}

Similar mechanical performance to conventional reactive powder concrete can be obtained by alkali-activated slag/silica fume, but the porosity and permeability of ARPC were much higher than CRPC. Thus, it may lead to early deppassivation of steel reinforcement. In the 
case of chloride environment corrosion propagation proceeds in a higher level in ARPC mixtures. Therefore, the cracking and damage occurrence began earlier in ARPC mixtures as compared to the CRPC mixtures. On the other hand, test results showed that the electrode potential shift in water environment especially for ARPC mixtures, was not an indicator of deteriorative corrosion activity in RPC mixtures.

\section{Acknowledgment}

This study was supported by the Scientific Research Council of Dokuz Eylül University (2009.KB.FEN009). The authors gratefully acknowledge for the financial support.

\section{References}

[1] Richard, P. and M.H. Cheyrezy, Reactive powder concretes with high ductility and 200$800 \mathrm{MPa}$ compressive strength. Special Publication. 144507-518, 1994.

[2] Aydın, S., Development of a Fiber Reinforced Composite with Alkali Activated Ground Granulated Blast Furnace Slag, in The Graduate School of Natural and Applied Sciences. 2010, Dokuz Eylul University: Turkey.

[3] Bonneau, O., et al., Characterization of the granular packing and percolation threshold of reactive powder concrete. Cement and Concrete Research. 30(12), 1861-1867, 2000.

[4] Ju, Y., et al., Toughness and characterization of reactive powder concrete with ultrahigh strength. Science in China Series E-Technological Sciences. 52(4), 1000-1018, 2009.

[5] Aydin, S. and B. Baradan, Effect of activator type and content on properties of alkaliactivated slag mortars. Composites Part B-Engineering. 57166-172, 2014.

[6] Aydin, S. and B. Baradan, Mechanical and microstructural properties of heat cured alkali-activated slag mortars. Materials \& Design. 35374-383, 2012.

[7] Aydin, S. and B. Baradan, The effect of fiber properties on high performance alkaliactivated slag/silica fume mortars. Composites Part B-Engineering. 45(1), 63-69, 2013.

[8] Aydin, S. and B. Baradan, Engineering Properties of Reactive Powder Concrete without Portland Cement. Aci Materials Journal. 110(6), 619-627, 2013.

[9] Aydin, S. and B. Baradan, High Temperature Resistance of Alkali-Activated Slag- and Portland Cement-Based Reactive Powder Concrete. Aci Materials Journal. 109(4), 463470, 2012.

[10] Wang, W.R., et al., Corrosion behavior of steel bars immersed in simulated pore solutions of alkali-activated slag mortar. Construction and Building Materials. 143289297, 2017.

[11] Ma, Q.M., et al., Chloride transport and the resulting corrosion of steel bars in alkali activated slag concretes. Materials and Structures. 49(9), 3663-3677, 2016. 
[12] Holloway, M. and J.M. Sykes, Studies of the corrosion of mild steel in alkali-activated slag cement mortars with sodium chloride admixtures by a galvanostatic pulse method. Corrosion Science. 47(12), 3097-3110, 2005.

[13] Babaee, M. and A. Castel, Chloride-induced corrosion of reinforcement in low-calcium fly ash-based geopolymer concrete. Cement and Concrete Research. 8896-107, 2016.

[14] Chaparro, W.A., J.H.B. Ruiz, and R.D.T. Gomez, Corrosion of Reinforcing Bars Embedded in Alkali-activated Slag Concrete Subjected to Chloride Attack. Materials Research-Ibero-American Journal of Materials. 15(1), 57-62, 2012.

[15] Aperador, W., R.M. de Gutierrez, and D.M. Bastidas, Steel corrosion behaviour in carbonated alkali-activated slag concrete. Corrosion Science. 51(9), 2027-2033, 2009.

[16] Monticelli, C., et al., A study on the corrosion of reinforcing bars in alkali-activated fly ash mortars under wet and dry exposures to chloride solutions. Cement and Concrete Research. 8753-63, 2016.

[17] ASTM C642-13. Standard Test Method for Density, Absorption, and Voids in Hardened Concrete. 2013, ASTM International: West Conshohocken, PA.

[18] ASTM C1202-05. Standard Test Method for Electrical Indication of Concrete's Ability to Resist Chloride Ion Penetration. 2005, ASTM International: West Conshohocken, PA.

[19] Monticelli, C., et al., Corrosion behavior of steel in alkali-activated fly ash mortars in the light of their microstructural, mechanical and chemical characterization. Cement and Concrete Research. 8060-68, 2016.

[20] Najimi, M., et al., Comparative Study of Alkali-Activated Natural Pozzolan and Fly Ash Mortars. Journal of Materials in Civil Engineering. 30(6), 2018.

[21] ASTM C876-09. Standard Test Method for Corrosion Potentials of Uncoated Reinforcing Steel in Concrete. 2009, ASTM International: West Conshohocken, PA.

[22] Yiğiter, H., The Determination Of Chloride Induced Corrosion Of Rebars By Electrochemical Methods, in The Graduate School of Natural And Applied Sciences. 2008, Dokuz Eylül University: Izmir.

[23] Yiğiter, H., et al., An Investigation On The Effects Of Cement Type And Concrete Quality On Durability Of Concrete And Rebar Corrosion Under Real Seawater Exposure. 2016, TÜBİTAK-Project No: 112M899: Izmir.

[24] Andrade, C., et al., Test methods for on-site corrosion rate measurement of steel reinforcement in concrete by means of the polarization resistance method. Materials and Structures. 37(273), 623-643, 2004. 